\title{
Use of immunochemistry in Britain: EQA Forum antibody usage questionnaire
}

\author{
CAROLE A ANGEL, EADIE HEYDERMAN, * I LAUDER \\ From the Department of Pathology, Leicester Royal Infirmary, Leicester, and the *Department of \\ Histopathology, UMDS, St Thomas's Hospital, London
}

SUMMARY A questionnaire was prepared under the auspices of the Department of Health with the aim of defining the extent and nature of immunocytochemistry use within pathology departments. The questionnaire was circulated to 320 pathology laboratories within the United Kingdom, and a total of 178 replies were received, representing a response rate of $56 \%$. One hundred and thirty eight $(78 \%)$ of the respondents used immunocytochemical techniques: 64 used immunocytochemical kits, including 35 district general hospital and 29 teaching hospital laboratories. An extensive range of antibodies was being used on a variety of tissues, epithelial and lymphoid markers far exceeding all other antibodies. Several differences in the numbers of cases and the types of tissues studied were identified among laboratories. The techniques used, the problems encountered, and the procedures followed with unsatisfactory reagents were also analysed. Finally, an assessment of the resources allocated to immunocytochemistry, both in terms of staff and reagent costs was made. Taking int $\varnothing$ account the response rate of $56 \%$ and the uncertainty that all pathology departments in the Unite Kingdom had been circulated, the estimated annual total costs for immunocytochemistry for a pathology laboratories in the United Kingdom was $£ 5.4$ million.

The use of immunocytochemical techniques has become widespread in the United Kingdom, but few data are available on exactly how and to what extent these techniques are used. A questionnaire circulated to district general hospital laboratories in 1986 indicated that $70.7 \%$ of these laboratories were using immunocytochemistry in routine diagnostic practice, ${ }^{1}$ but no comparable data are available for teaching hospital laboratories.

A questionnaire was prepared by two of the authors (EH, IL) with the aim of defining the extent of use of immunocytochemistry within pathology departments in the United Kingdom, the type and range of tests being performed, the techniques being used, the problems associated with immunocytochemistry and the extent of kit use were analysed. Differences between methods of use in laboratories in district

Accepted for publication 25 May 1989 general hospitals and teaching hospitals were also defined. An assessment of the associated staff and reagent costs was used to provide an estimated total cost for all pathology departments in the United Kingdom.

\section{Methods}

The questionnaire (copy available on request) was $\frac{D}{O}$ circulated to a total of 320 pathology laboratories throughout the United Kingdom using a list of $N$ histopathologists and immunopathologists provided by the Royal College of Pathologists. Information $\mathrm{N}$ sought included types of antibodies used, types of $\omega$ tissues studied, and numbers of cases analysed. The extent of kit use, the commercial suppliers used, and 0 technical details involved in immunocytochemistry $\mathbb{D}$ were also requested. The results were collated, entered $\cdot$ into a computerised database, and analysed statistically. 
Table 1 No (\%) of laboratories and hospitals replying to questionnaire

\begin{tabular}{lcll}
\hline & $\begin{array}{l}\text { District } \\
\text { general } \\
\text { hospital }\end{array}$ & $\begin{array}{l}\text { Teaching } \\
\text { hospital }\end{array}$ & Total \\
\hline $\begin{array}{l}\text { Laboratory type } \\
\text { Hospital type }\end{array}$ & $126(71)$ & $52(29)$ & $178(100)$ \\
$\begin{array}{l}\text { No performing immuno- } \\
\text { cytochemistry }\end{array}$ & $118(74)$ & $41(26)$ & $159(100)$ \\
$\begin{array}{l}\text { No using kits } \dagger \\
\text { Percentage using kitsł }\end{array}$ & $91(72)$ & $47(90)$ & $138(78)$ \\
\hline
\end{tabular}

*Percentage calculated from number of laboratories/total number of respondents $(n=178)$.

†Percentage calculated from number of laboratories using kits/total number of respondents $(n=178)$.

$\ddagger$ Percentage calculated from number of laboratories using kits/total number of immunocytochemistry using laboratories $(n=138)$.

\section{Results}

Of the 320 laboratories, $178(56 \%)$ replied to the questionnaire, about $70 \%$ of which were in district general hospitals and the rest in teaching hospitals (table 1). The actual proportion of hospital types was slightiy different because some hospitals had up to three laboratories actively using immunocytochemical methods as part of the diagnostic service. The proportion of teaching hospital respondents $(65 \%)$ was higher than the proportion of district general hospital respondents $(53 \%)$. Table 1 shows the number of both hospital laboratory types performing immunocytochemistry, together with the number using immunocytochemical kits. Forty $(22 \%)$ laboratories reported no use of immunocytochemical techniques, five in teaching hospitals and 35 in district general hospitals.

Table 2 shows the types of tissues which had been subjected to immunocytochemical analysis, the number of cases studied, and the mean number of antibodies used to study each case during a single month. Although there were almost twice as many district general hospital laboratories as teaching hospital laboratories using immunocytochemistry, the number of cases was much higher in teaching hospitals
Table 3 Suppliers

\begin{tabular}{llll}
\hline Supplier & $\begin{array}{l}\text { No (\%) of } \\
\text { laboratories }\end{array}$ & Supplier & $\begin{array}{l}\text { No (\%) of } \\
\text { laboratories }\end{array}$ \\
\hline Dako & $135(98)$ & BDH & $29(21)$ \\
Becton Dickinson & $76(55)$ & Ortho & $22(16)$ \\
Unipak & $55(40)$ & Biotest & $18(13)$ \\
Sigma & $53(38)$ & Coulter & $15(11)$ \\
Miles & $48(35)$ & Nordic & $14(10)$ \\
Bionuclear & $47(34)$ & RIA & $8(6)$ \\
Amersham & $41(30)$ & Cambridge & $4(3)$ \\
Janssen & $35(25)$ & Travenol & $3(2)$ \\
Seralab & $35(25)$ & & \\
\hline
\end{tabular}

Percentages calculated from number of laboratories/total number of laboratories using immunocytochemistry $(n=138)$.

for all tissue types studied. Analysis of lymphoid and epithelial samples far exceeded that of other tissues in both hospital laboratory types. Lymph node analysis was performed more frequently than analysis of other tissues in teaching hospital laboratories, but in district general hospital laboratories analysis of epithelial tissues predominated. The mean number of antibodies for each case was consistently higher in teaching hospital laboratories than in district general hospital laboratories.

The companies supplying antibodies to the 138 laboratories using immunocytochemistry are listed in table 3. Dako supplied almost all the laboratories using immunocytochemistry; among the other suppliers only Becton Dickinson exceeded $50 \%$. Ortho supplied only $16 \%$ of laboratories with primary antibodies, whereas they supplied $46(32 \%)$ of laboratories using kits (table 4). When asked to recommend a particular manufacturer, $93(67 \%)$ of the immunocytochemistry laboratories suggested Dako, with much smaller numbers recommending Becton Dickinson, Eurodiagnostics, or other companies.

Table 5 lists the primary antibodies used by the laboratories in order of greatest use, and illustrates the very wide range of antibodies being used. Not surprisingly, in view of the fact that lymph node analysis was frequently performed by both hospital types,

Table 2 Tissue tests carried out during March 1987

\begin{tabular}{|c|c|c|c|c|c|c|}
\hline \multirow[b]{2}{*}{ Tissue type } & \multicolumn{3}{|c|}{ No of cases } & \multicolumn{3}{|c|}{ Mean No of antibodies/case } \\
\hline & Total & $\begin{array}{l}\text { District } \\
\text { general } \\
\text { hospital }\end{array}$ & $\begin{array}{l}\text { Teaching } \\
\text { hospital }\end{array}$ & Total & $\begin{array}{l}\text { District } \\
\text { general } \\
\text { hospital }\end{array}$ & $\begin{array}{l}\text { Teaching } \\
\text { hospital }\end{array}$ \\
\hline $\begin{array}{l}\text { Renal } \\
\text { Skin } \\
\text { Lymph node } \\
\text { Epithelial } \\
\text { Endocrine } \\
\text { Germ cell } \\
\text { Soft tissue } \\
\text { Others } \\
\text { Total }\end{array}$ & $\begin{array}{r}332 \\
379 \\
714 \\
772 \\
179 \\
144 \\
205 \\
356 \\
3081\end{array}$ & $\begin{array}{r}79 \\
128 \\
236 \\
396 \\
51 \\
25 \\
64 \\
196 \\
1175\end{array}$ & $\begin{array}{r}253 \\
251 \\
478 \\
37.6 \\
128 \\
119 \\
141 \\
160 \\
1906\end{array}$ & $\begin{array}{l}7 \cdot 0 \\
4 \cdot 8 \\
6 \cdot 2 \\
2 \cdot 8 \\
2 \cdot 8 \\
2 \cdot 5 \\
3 \cdot 8 \\
2 \cdot 7 \\
4 \cdot 1\end{array}$ & $\begin{array}{l}5 \cdot 4 \\
4 \cdot 6 \\
5 \cdot 1 \\
2 \cdot 6 \\
2 \cdot 3 \\
2 \cdot 1 \\
3 \cdot 5 \\
2 \cdot 3 \\
3 \cdot 5\end{array}$ & $\begin{array}{l}8 \cdot 7 \\
5 \cdot 2 \\
8 \cdot 3 \\
3 \cdot 3 \\
3 \cdot 1 \\
2 \cdot 9 \\
4 \cdot 1 \\
3 \cdot 2 \\
4 \cdot 9\end{array}$ \\
\hline
\end{tabular}


Table 4 Kit suppliers

\begin{tabular}{llll}
\hline & \multicolumn{3}{l}{ No of laboratories } \\
\cline { 2 - 4 } Supplier & $\begin{array}{l}\text { Teaching } \\
\text { hospital }\end{array}$ & $\begin{array}{l}\text { District } \\
\text { general } \\
\text { hospital }\end{array}$ & Total (\%) \\
\hline Dako & 24 & 33 & $57(40)$ \\
Ortho & 20 & 26 & $46(32)$ \\
Vector & 5 & 3 & $8(6)$ \\
ICN & 2 & 4 & $6(4)$ \\
CMD & 0 & 5 & $5(4)$ \\
Amersham & 4 & 0 & $4(3)$ \\
BSC & 4 & 0 & $4(3)$ \\
Others & 6 & 6 & $12(8)$ \\
Total & & & $142(100)$ \\
\hline
\end{tabular}

leucocyte common antigen and immunoglobulins were used most often.

The immunocytochemical techniques used and the number of problems associated with these techniques are shown in table 6 . Laboratories frequently used more than one technique routinely, and often used other techniques occasionally. Pronounced differences between district general hospital laboratories and teaching hospital laboratories were not noted. The techniques most frequently used routinely were peroxidase antiperoxidase (PAP) $73(53 \%)$ and the indirect immunoperoxidase methods $62(45 \%)$. Occasional problems with all the techniques used were reported by up to half of the users, most problems being encountered with the PAP technique and least with immunofluorescence. Avidin-biotin (30, 22\%) and alkaline phosphatase anti-alkaline phosphatase $(18,13 \%)$ were less frequently used, and the number of problems met with using these techniques was slightly lower than those encountered with PAP.

The questionnaire requested details of further aspects of the techniques used, including chromogens, buffers, and fixation for both paraffin wax embedded and frozen material. Diaminobenzidine (DAB) was the commonest chromogen in use, but other frequently used chromogens were Fast red and AEC (3amino-9-ethylcarbazole). Both TRIS and phosphate buffered saline (PBS) buffers were used extensively. Neutral buffered formalin was the fixative favoured by most laboratories for both large and small specimens $78(62 \%)$, with smaller numbers of laboratories 31 (26\%) using formol-saline. Other fixatives such as unbuffered formalin, formol sublimate, and Bouin's fluid were less frequently used $(9 \%)$. Seventy $(59 \%)$ laboratories preferred acetone as the fixative for frozen sections.

Use of kits was reported by 64 laboratories, 35 in district general hospitals and 29 in teaching hospital laboratories (table 1). Of the total number of laboratories in district general hospitals using immunocytochemistry, $38 \%$ used kits, in contrast to teaching hospital laboratories, where $62 \%$ used kits.
Table 5 Primary antibodies used

\begin{tabular}{|c|c|c|c|}
\hline Antibody & $\begin{array}{l}\text { No }(\%) \text { of } \\
\text { laboratories }\end{array}$ & Antibody & $\begin{array}{l}\text { No (\%) of } \\
\text { laboratories }\end{array}$ \\
\hline $\begin{array}{l}\text { Leucocyte common } \\
\text { antigen } \\
\text { Immunoglobulins } \\
\text { Keratin } \\
\text { Epithelial membrane } \\
\text { antigen } \\
\text { Carcinoembryonic } \\
\text { antigen } \\
\text { Alpha-1- } \\
\text { antitrypsin } \\
\text { S100 } \\
\text { Lysozyme } \\
\text { Alpha-feto- } \\
\text { protein } \\
\text { T cell } \\
\text { B cell } \\
\text { Chorionic } \\
\text { gonadotrophin } \\
\text { Prostate specific } \\
\text { antigen } \\
\text { Vimentin } \\
\text { Factor VIII related } \\
\text { antigen } \\
\text { Desmin } \\
\text { Complement } \\
\text { Neuron specific } \\
\text { enolase }\end{array}$ & $\begin{array}{r}123 \\
118 \\
116 \\
114 \\
100 \\
100 \\
99 \\
98 \\
89 \\
88 \\
86 \\
84 \\
83 \\
80 \\
77 \\
70 \\
63\end{array}$ & $\begin{array}{l}\text { Glial fibrillary } \\
\text { acidic protein } \\
\text { Prostatic acid } \\
\text { phosphatase } \\
\text { Fibrinogen } \\
\text { Thyroglobulin } \\
\text { Anti-Leu M1 } \\
\text { Hepatitis B } \\
\text { antigen } \\
\text { Calcitonin } \\
\text { Papillomavirus } \\
\text { Somatostatin } \\
\text { Insulin } \\
\text { Glucagon } \\
\text { Pre-albumin } \\
\text { Pituitary } \\
\text { hormones } \\
\text { Herpes simplex } \\
\text { virus } \\
\text { Myoglobin } \\
\text { Human placental } \\
\text { lactogen } \\
\text { Alpha-1-anti- } \\
\text { chymotrypsin } \\
\text { Neurofilaments }\end{array}$ & $\begin{array}{l}59 \\
57 \\
57 \\
46 \\
43 \\
40 \\
33 \\
31 \\
29 \\
29 \\
28 \\
24\end{array}$ \\
\hline
\end{tabular}

The number of different kits used for each laboratory varied between one and nine, with most laboratories using just one or two types of kit. Table 4 shows tha Dako supplied $57(40 \%)$ and Ortho $46(32 \%)$ of the kits used. Between them, Dako and Ortho supplied 45 $(70 \%)$ of the laboratories with at least one kit.

One hundred and forty two different types of kits were used, and these could be divided into two broad groups. The first and largest group $(n=100)$ comprised those kits which include one or more primary antibodies such as prostatic acid phosphatase and hepatitis B surface antigen. The second group $(n=42)$ were kits for one technique only which did not include a primary antibody-for example, ABComplex HRP (Dako k355), Universal PAP kit. Table 7 shows the range of kits used by the laboratories in the first group. A wide range of antibodies was being used in kit form,

Table 6 Techniques used and problems encountered

\begin{tabular}{lll}
\hline Technique & $\begin{array}{l}\text { No }(\%) \text { of users } \\
\text { Usual/occasional* }\end{array}$ & $\begin{array}{l}\text { No (\%) of users } \\
\text { with problemst }\end{array}$ \\
\hline PAP & $73(53) / 31(22)$ & $53(51)$ \\
Indirect & $62(45) / 34(25)$ & $45(47)$ \\
Immunofiuorescence & $40(29) / 23(17)$ & $23(37)$ \\
AB & $30(22) / 28(20)$ & $23(40)$ \\
APAAP & $18(13) / 35(25)$ & $25(47)$ \\
Direct & $12(9) / 20(14)$ & $13(41)$ \\
\hline
\end{tabular}

* Percentages calculated from number of laboratories using technique/total number of laboratories using immunocytochemistry (138).

†Percentages calculated from number of laboratories reporting problems/number of laboratories using technique. 
Table 7 Use of kits with a primary antibody

\begin{tabular}{|c|c|c|}
\hline & Total & $\begin{array}{l}\text { District general } \\
\text { hospital/Teaching } \\
\text { hospital }\end{array}$ \\
\hline \multicolumn{3}{|l|}{ Immunoglobulins/lymphoma markers: } \\
\hline $\begin{array}{l}\text { Anaplastic tumour kit (LCA and } \\
\text { EMA) }\end{array}$ & 7 & $7 / 0$ \\
\hline IgA, IgG, IgM & 2 & $2 / 0$ \\
\hline Kappa, lambda, lysozyme & 2 & $2 / 0$ \\
\hline Leucocyte common antigen & 2 & $2 / 0$ \\
\hline Kappa & $\overline{1}$ & $1 / 0$ \\
\hline Lambda & 1 & $1 / 0$ \\
\hline J-chain & 1 & $0 / 1$ \\
\hline Lymphoma identification kit & 1 & $1 / 0$ \\
\hline \multicolumn{3}{|l|}{ Hormones: } \\
\hline Pancreatic and related hormones & 17 & $2 / 15$ \\
\hline Pituitary hormones & 4 & $1 / 3$ \\
\hline Others & 6 & $1 / 5$ \\
\hline \multicolumn{3}{|l|}{ Enzymes: } \\
\hline Prostatic acid phosphatase & 7 & $5 / 2$ \\
\hline Lysozyme & 1 & $1 / 0$ \\
\hline Alpha-1-antitrypsin & 1 & $1 / 0$ \\
\hline Alpha-1-antichymotrypsin & 1 & $1 / 0$ \\
\hline \multicolumn{3}{|c|}{ Tissue specific markers/other cellular antigens: } \\
\hline Keratin & 5 & $5 / 0$ \\
\hline Carcinoembryonic antigen & 5 & $4 / 1$ \\
\hline Factor VIII related antigen & 3 & $3 / 0$ \\
\hline Prostate specific antigen & 3 & $2 / 1$ \\
\hline $\mathbf{S 1 0 0}$ & 3 & $2 / 1$ \\
\hline Neuron specific enolase & 2 & $1 / 1$ \\
\hline Myoglobin & 2 & $0 / 2$ \\
\hline Alpha-fetoprotein & 2 & $1 / 1$ \\
\hline CA 125 & 2 & $0 / 2$ \\
\hline Oestrogen receptors & 2 & $1 / 1$ \\
\hline $\begin{array}{l}\text { TDT } \\
\text { Epithelial membrane antigen }\end{array}$ & 2 & $\begin{array}{l}1 / 1 \\
1 / 0\end{array}$ \\
\hline Glial fibrillary acidic protein & 1 & $\begin{array}{l}1 / 0 \\
1 / 0\end{array}$ \\
\hline \multicolumn{3}{|l|}{ Infective agents: } \\
\hline Hepatitis B surface antigen & 7 & $5 / 2$ \\
\hline Others & 6 & $3 / 3$ \\
\hline Total & 100 & $58 / 42$ \\
\hline
\end{tabular}

LCA = leucocyte common antigen, EMA = epithelial membrane antigen.

and some differences among the kits used by laboratories in district general hospitals and teaching hospitals were noted.

A breakdown of the techniques used in all 142 different kits is provided in table 8 , and the techniques provided in kit form are also shown. The most frequently used technique was the PAP technique, but kits providing PAP as a technique only, without a primary antibody, were rarely purchased, and $A B C$ kits were preferred.

\section{FINANCIAL CONSIDERATIONS}

Tables 9 and 10 deal with the resources allocated to immunocytochemistry within the 138 laboratories. A total of 240.6 staff (expressed in whole time equivalents) was used by the laboratories in performing immunocytochemical techniques. The total number of whole time equivalents at the Scientific (PTA) grade was very low $(5 \cdot 5)$, and most work was being performed by MLSO (PTB) grades.
Table 8 Techniques used in kits

\begin{tabular}{|c|c|c|c|c|}
\hline \multirow[b]{2}{*}{ Technique } & \multicolumn{2}{|c|}{ All kits } & \multicolumn{2}{|c|}{ 'Technique kits' } \\
\hline & Total & $\begin{array}{l}\text { District } \\
\text { general } \\
\text { hospital/ } \\
\text { Teaching } \\
\text { hospital }\end{array}$ & Total & $\begin{array}{l}\text { District } \\
\text { general } \\
\text { hospital/ } \\
\text { Teaching } \\
\text { hospital }\end{array}$ \\
\hline $\begin{array}{l}\text { Peroxidase-anti- } \\
\text { peroxidase } \\
\text { Avidin-biotin-peroxidase } \\
\text { Indirect immunoperoxidase }\end{array}$ & $\begin{array}{r}89 \\
25 \\
9\end{array}$ & $\begin{array}{c}51 / 38 \\
11 / 14 \\
8 / 1\end{array}$ & $\begin{array}{r}3 \\
22 \\
0\end{array}$ & $\begin{array}{c}3 / 10 \\
10 / 12 \\
0 / 0\end{array}$ \\
\hline $\begin{array}{l}\text { Streptavidin-biotin- } \\
\text { peroxidase } \\
\text { Dinitrophenol localisation }\end{array}$ & 6 & $4 / 2$ & 4 & $2 / 2$ \\
\hline $\begin{array}{l}\text { system } \\
\text { Immunogold-silver } \\
\text { Avidin-biotin-alkaline }\end{array}$ & $\begin{array}{l}4 \\
4\end{array}$ & $\begin{array}{l}0 / 4 \\
2 / 2\end{array}$ & $\begin{array}{l}4 \\
4\end{array}$ & $\begin{array}{l}0 / 4 \\
2 / 2\end{array}$ \\
\hline $\begin{array}{l}\text { phosphatase } \\
\text { Immunofluorescence }\end{array}$ & $\begin{array}{l}2 \\
2\end{array}$ & $\begin{array}{l}2 / 0 \\
0 / 2\end{array}$ & $\begin{array}{l}2 \\
0\end{array}$ & $\begin{array}{l}2 / 0 \\
0 / 0\end{array}$ \\
\hline oxidase & 1 & $0 / 1$ & 1 & $0 / 1$ \\
\hline Total & 142 & $78 / 64$ & 42 & $19 / 23$ \\
\hline
\end{tabular}

Table 10 shows that both reagent and staff costs were considerably higher in teaching hospital than in district general hospital laboratories, and the total cost of immunocytochemistry in teaching hospital laboratories was about twice that in district general hospital laboratories. A small number of the laboratories were unable or unwilling to supply detailed figures for reagent costs, and an estimate has been made for those missing values using the mean values derived from those laboratories $(n=131)$ who did provide detailed figures. The final estimate of likely total expenditure in the United Kingdom was again based on the mean values for staff and reagent costs to provide an estimate of expenditure for a total of 320 laboratories (240 district general hospital and 80 teaching hospital laboratories).

Table 9 Resources - staff numbers

\begin{tabular}{lccc}
\hline & \multicolumn{3}{l}{ No of staff (whole time equivalents) } \\
\cline { 2 - 4 } & $\begin{array}{l}\text { District } \\
\text { general } \\
\text { hospital }\end{array}$ & $\begin{array}{l}\text { Teaching } \\
\text { hospital }\end{array}$ & Total \\
\hline MLSO PTB: & & & \\
Senior chief & 6.0 & 4.9 & 10.9 \\
Chief & 22.7 & 17.6 & 40.3 \\
Senior & 37.9 & 30.3 & 68.2 \\
Basic grade & 44.2 & 52.9 & 97.1 \\
Junior & 9.7 & 8.9 & 18.6 \\
Total & $120.5(1.3)^{*}$ & $114.6(2.4)^{*}$ & $235.1(1.7)^{*}$ \\
Scientific PTA: & & & \\
Principal & 0.0 & 0.0 & 0.0 \\
Senior & 1.5 & 1.0 & 2.5 \\
Basic grade & 0.0 & 3.0 & 3.0 \\
Total & 1.5 & 4.0 & 5.5 \\
Total staff & $122.0(1.3)^{*}$ & $118.6(2.5)^{*}$ & $240.6(1.7)^{*}$ \\
\hline
\end{tabular}

* Means calculated from number of staff/total number of laboratories using immunocytochemistry. 
Table 10 Resources - reagent and staff costs

\begin{tabular}{|c|c|c|c|}
\hline & \multicolumn{3}{|c|}{ Costs (£) (mean value below) } \\
\hline & $\begin{array}{l}\text { District } \\
\text { general } \\
\text { hospital }\end{array}$ & $\begin{array}{l}\text { Teaching } \\
\text { hospital }\end{array}$ & Total \\
\hline Reagents* & $\begin{array}{r}146924 \\
(1670)\end{array}$ & $\begin{array}{r}185576 \\
(4316)\end{array}$ & $\begin{array}{r}332499 \\
(2538)\end{array}$ \\
\hline Staff & $\begin{array}{r}1099781 \\
(12086)\end{array}$ & $\begin{array}{r}1043400 \\
(22200)\end{array}$ & $\begin{array}{rl}2 & 143181 \\
& (15530)\end{array}$ \\
\hline Total & $\begin{array}{r}1246705 \\
(13700)\end{array}$ & $\begin{array}{r}1228976 \\
(26148)\end{array}$ & $\begin{array}{r}2475680 \\
(17940)\end{array}$ \\
\hline $\begin{array}{l}\text { Estimate for missing } \\
\text { reagent costs }\end{array}$ & 5010 & 17264 & 22274 \\
\hline Estimated total & $\begin{array}{r}1251715 \\
(13755)\end{array}$ & $\begin{array}{r}1246240 \\
\quad(26516)\end{array}$ & $\begin{array}{r}2497955 \\
(18101)\end{array}$ \\
\hline $\begin{array}{l}\text { Estimate for all } \\
\text { pathology laboratories } \\
\text { in United Kingdom } †\end{array}$ & 3301200 & 2121280 & 5422480 \\
\hline
\end{tabular}

*Based on 131 replies (88 District general hospitals, 43 Teaching hospitals).

†Based on 320 laboratories (240 District general hospitals, 80 Teaching hospitals).

Assuming that the average laboratory buys one kit of each type a year, the percentage of the total amount spent on immunocytochemical reagents a year can be estimated. Laboratories in teaching hospitals used an average of $8 \%$ of the total amount spent on immunocytochemical reagents to buy kits; the corresponding figure for laboratories in district general hospitals was $28 \%$. In district general hospital laboratories $75 \%$ of the total amount spent on kits was used to buy complete kits-that is, those in which a primary antibody is included; in teaching hospital laboratories this proportion was lower $(60 \%)$.

\section{Discussion}

Responses from the 178 laboratories indicated that about $70 \%$ of district general hospital laboratories were using immunocytochemistry, while for teaching hospital laboratories this figure was $\mathbf{9 0 \%}$. The small number of teaching hospital laboratories not performing immunocytochemistry can be explained by the inclusion of some specialised departments such as forensic and ophthalmology laboratories. All of the teaching hospital laboratories that were not highly specialised were using immunocytochemical techniques routinely. Among those district general hospital laboratories not performing immunocytochemistry at the time the questionnaire was circulated, many indicated that they would either be setting up these techniques in the near future, or that they would like to see immunocytochemistry techniques established within their laboratories, provided that adequate resources could be obtained.

Teaching hospital laboratories performed immunocytochemical tests on a much higher number of cases than district general hospital laboratories, and the mean number of antibodies used to analyse each case was consistently higher in teaching hospital laboratories than in district general hospital laboratories. In teaching hospital laboratories lymph node analysis exceeded that of other tissues by far, while although lymph node analysis was frequently performed in district general hospital laboratories, epithelial tissues were more commonly studied. The larger number of antibodies used for each case in teaching hospital laboratories implies that these laboratories more frequently analysed tissues using panels of antisera.

The reasons for these variations between hospital laboratory types are probably complex, and may include factors such as availability of resources and a differing emphasis on research and developmental aspects of immunocytochemistry. Although the questionnaire asked laboratories to estimate the relative proportions of diagnostic and research work performed, some laboratories found this difficult to answer, because they could not clearly separate the diagnostic from the research and developmental applications of their work. From the 126 laboratories able to provide an answer, it was calculated that $92 \%$ of immunocytochemistry in district general hospital laboratories and $62 \%$ in teaching hospital laboratories is diagnostice्e This difference may in part account for some of the differences between hospital laboratory types.

A larger proportion of laboratories in teaching hospitals $(64 \%)$ use kits when compared with laboratories in district general hospitals (38\%). Because kits supply reagents pre-diluted and ready to use, it was anticipated that their use would appeal more to smaller laboratories in district general hospitals with relatively less experienced staff. A detailed breakdown of the costs involved in kit usage, however, shows that district general hospital laboratories use a much larger proportion of the money they spend on immunocytochemical reagents to buy kits $(28 \%)$ than teaching hospital laboratories $(8 \%)$. Differences in the types of kits purchased by the hospital laboratory types were also noted. For example, the Anaplastic Tumour Kit, marketed by Dako, and intended to allow anaplastic tumours to be divided into the two broad groups of carcinoma or lymphoma, was used exclusively by district general hospital laboratories. This may partly reflect the much higher percentage of diagnostic immunocytochemistry done in district general hospital laboratories $(92 \%)$ in contrast to teaching hospital laboratories (62\%). Almost all of the kits detecting hormones were bought by laboratories in teaching hospitals, which again may reflect a higher interest in this field in teaching hospital laboratories. Although lymph node analysis was more frequently

\section{$\vec{\circ}$}


performed in teaching hospital than in district general hospital laboratories, most of the kits for identification and characterisation of lymphomas were bought by laboratories in district general hospitals.

Occasional problems with detection techniques were encountered in up to half the laboratories with all the techniques used. The number of problems met with was slightly lower with the avidin-biotin and APAAP techniques than with the PAP technique, but this may reflect the lower incidence of usage of these techniques by the responding users. The avidin-biotin technique is more frequently used in kit form than other detection techniques (table 8), although the majority of "complete" kits-those detailed in table 7-used the PAP technique.

The respondents were asked what procedures were followed when unsatisfactory reagents were discovered. The general low level of response (61 laboratories) to this question could indicate either a general satisfaction with the currently available reagents, or that without some system of quality control many of the laboratories were unaware that the particular antibodies in use were unsatisfactory. The two most common responses were either to exchange the reagent for another sample of the same antibody, or to change the supplier. Serious defects should be reported to the Department of Health NHS Procurement Directorate.

The estimated total annual cost of immunocytochemistry in the United Kingdom may well be an underestimate as the precise number of laboratories is uncertain. The information provided by the Royal College of Pathologists was in the form of a set of addresses of known immunopathologists and histopathologists in the United Kingdom. About a quarter of the addresses were home addresses rather than those of the individual departments, and the precise number of laboratories still has to be established.
Until a more accurate list is compiled the overall usage must be regarded only as an estimate, and any detailed analysis of costs should take this factor into consideration.

Considerable sums of money are involved, and it seems likely that much duplication of testing of new reagents is being performed. The Department of Health has already commissioned a number of studies of readily available commercial primary antibodies and detection techniques. ${ }^{2}$ Several of the respondents to the questionnaire previously circulated by Hall et al indicated that the establishment of a national database supplying data of this kind would be welcomed. At a time when there is considerable emphasis on cost reduction, many find excessive the costs of investigating new sources of reagents or redoing tests performed with antibodies or kits which turn out to be unsatisfactory.

We thank all those respondents who took the time and the trouble to reply to this questionnaire. We also thank Dr Howard Pringle for his invaluable help in helping to set up the database, the secretarial staff of the University of Leicester department of pathology for entering the data, and the Royal College of Pathologists for supplying the list of pathologists.

\section{References}

1 Hall PA, Domizio P, Slavin G, Levison DA. Immunohistochemistry in district general hospitals in England and Wales. $J$ Clin Pathol 1987;40:1305-9.

2 Angel CA, Warford A, Day SJ, Lauder I. Comparative quality assessment in immunocytochemistry: pilot study of CD15 staining in paraffin wax embedded tissue in Hodgkin's disease. $J$ Clin Pathol 1989;42:1196-200.

Requests for reprints to: Dr Carole A Angel, Department of Pathology, Clinical Sciences Building, Leicester Royal Infirmary, PO Box 65, Leicester LE2 7LX, England. 